\author{
Revista Brasileira de Educação do Campo \\ Brazilian Journal of Rural Education \\ ARTIGO/ARTICLE/ARTÍCULO \\ DOI: $\underline{\text { http://dx.doi.org/10.20873/uft.rbec.e12647 }}$
}

\title{
Organization of the educational process in the Rural School of the mountain region: a case study
}

\footnotetext{
Olena Budnyk ${ }^{1}$, (D) Inna Nikolaesku², iD Nataliia Stepanova ${ }^{3}$, iD Olena Vovk ${ }^{4}$, iD Anna Palienko ${ }^{5}$ (iD) Tetiana Atroshchenko ${ }^{6}$

${ }^{1}$ Vasyl Stefanyk Precarpathian National University. Department of Pedagogy of Primary Education, Director of the Center for Innovative Educational Technologies "PNU EcoSystem". 57 Shevchenko St. Ivano-Frankivsk 76018 Ukraine. ${ }^{2,3,4,5}$ Bohdan Khmelnytsky National University at Cherkasy, Cherkasy, Ukraine. ${ }^{6}$ Mukachevo State University, Mukachevo, Ukraine.
}

Author for correspondence: olena.budnyk@gmail.com

\begin{abstract}
The purpose of the article is to present the problems of a typical rural school in a mountainous region in terms of the organization of the educational process, in particular distance learning of students in a coronary virus pandemic. The following research methods were used: analyticsynthetic, empirical and mathematical statistics. The specifics of the organization of schoolchildren's education in the alpine conditions of a small rural school are substantiated. The results of an empirical study conducted among teachers of rural schools in the mountains of Ukraine are presented. The subject of the survey were questions about the attitude of teachers to distance learning in rural schools, the realities and difficulties of using information and communication technologies (ICT) in the educational process. It was found that among teachers of various levels of rural education (preschool, primary and secondary school) $49.12 \%$ have a positive attitude to distance learning, $18.42 \%$ - partially support. Given the difficulties and problems of using ICT, lack of teaching materials for online learning, low level of digital and media literacy, 23.68\% of teachers - strongly against this form of organization of the educational process in remote rural (mountainous) regions. Prospects for the development of rural schools in mountainous areas in the context of digitalization of education are identified.
\end{abstract}

Keywords: educational process in a mountainous school, rural school, distance learning, digital technologies.

\begin{tabular}{|l|l|l|l|l|l|l|} 
RBEC & Tocantinópolis/Brasil & v. 6 & e12647 & $10.20873 /$ uft.rbec.e12647 & 2021 & ISSN: 2525-4863 \\
\hline
\end{tabular}




\section{Organização do processo educativo na Escola Rural da região montanhosa: um estudo de caso}

RESUMO. O objetivo do artigo é apresentar a problemática de uma típica escola rural de uma região montanhosa no que se refere à organização do processo educacional, em particular ao ensino à distância de alunos em uma pandemia de vírus coronariano. Foram utilizados os seguintes métodos de pesquisa: analíticos e sintéticos, empíricos e estatística matemática. Fundamentamos as especificidades da organização da educação dos alunos nas condições de montanha alta de uma pequena escola rural. Apresentamos os resultados de um estudo empírico realizado no meio de professores das escolas rurais nas localidades montanhosas da Ucrânia. No questionário foram incluídas as questões sobre a atitude dos professores em relação à educação à distância em escolas rurais, as realidades e as dificuldades do uso das tecnologias de informação e comunicação (TIC) no processo educativo. Verificou-se que entre os professores de diferentes níveis de ensino rural (préescolar, ensino primário e secundário) 49,12\% têm atitude positiva em relação às TIC, $18,42 \%$ - demonstram o apoio parcial. Dadas as dificuldades e problemas de uso das TIC, falta de materiais didáticos para aprendizagem online, baixo nível de alfabetização digital e midiática, 23,68\% estão fortemente contra essa forma de organização do processo educativo em regiões rurais remotas (montanhosas). Foram determinadas as perspectivas de desenvolvimento de escolas rurais em áreas montanhosas no contexto de digitalização da educação.

Palavras-chave: processo educativo, escola de montanha, escola rural, ensino à distância, tecnologias digitais. 


\section{Organización del proceso educativo en Escuelas Rurales de la región montañosa: un estudio de caso}

RESUMEN. En el artículo presentamos el problema de una escuela rural típica en una región montañosa en cuanto a la organización del proceso educativo, el aprendizaje a distancia de los estudiantes en condiciones de pandemia de coronavirus, en particular. Se utilizaron los siguientes métodos de investigación: estadística analítica y sintética, empírica y matemática. Comprobamos los detalles de la organización de la educación de los estudiantes en las condiciones de alta montaña de una pequeña escuela rural. Presentamos los resultados de un estudio empírico realizado entre profesores de escuelas rurales en zonas montañosas de Ucrania. El cuestionario incluyó preguntas sobre la actitud de los docentes en relación a la educación a distancia en las escuelas rurales, las realidades y dificultades en el uso de las tecnologías de la información y la comunicación (TIC) en el proceso educativo. Se encontró que entre los docentes de diferentes niveles de educación rural (educación preescolar, primaria y secundaria) el 49,12\% tiene una actitud positiva hacia las TIC, el 18,42\% - demuestra apoyo parcial. Dadas las dificultades y problemas del uso de las TIC, la falta de materiales didácticos para el aprendizaje en línea, el bajo nivel de alfabetización digital y mediática, el 23,68\% se opone fuertemente a esta forma de organización del proceso educativo en regiones rurales remotas (montañosas). Se determinaron las perspectivas de desarrollo de escuelas rurales en zonas montañosas en el contexto de la digitalización de la educación.

Palabras clave: proceso educativo, escuela de montaña, escuela rural, la educación a distancia, tecnologías digitales. 


\section{Introduction}

In the conditions of integration, social processes, globalization and digitalization, the requirements for the quality of educational services in various types of educational establishments are growing. The outlined problem is extremely relevant in the context of preparing teachers for social work in schools of remote rural (mountainous) areas, where a significant number of children and youth need especially psychological and pedagogical support. These include children of migrant workers, orphans/semi-orphans, people from lowincome or large families, and others (Budnyk, Nikolaesku, Atroshchenko et al., 2021).

Educational establishments located in the Appalachian, Alps, Apennines or Pontic Mountains have an extremely welldeveloped infrastructure and a universal educational design that solves the problem of, for example, their accessibility. We have somewhat different conditions in the Ukrainian Carpathians, where teachers and education managers face numerous problems with the organization of the educational process in kindergartens and schools, the introduction of inclusion or work with students from particularly vulnerable groups, the use of digital technologies in education and others.
In the context of urbanization, it is important to adapt rural schools, which are often in difficult socio-economic and socio-cultural conditions. "Urban normativity helps contextualize the marginalized nature of rural schools within the larger educational system" (Zinger, Haymore Sandholtz \& Ringstaff, 2020). Rural schools are not heterogeneous, however, and have their own specifics regarding location, population, and histories.

One of the biggest problems in South Africa is rural poverty and the education system, as rural areas are relatively underdeveloped and negatively affect the quality of schooling. Among such difficulties: lack of basic infrastructure, insufficient amount of drinking water, electricity, transport, information and communication technologies, books and educational materials, etc., they need to provide the necessary psychological and pedagogical support of students (Du Plessis, 2014). Such issues are relevant for many countries.

For all rural (mountainous) schools, the problem of providing an educational establishment with highly qualified teachers who could teach several subjects is relevant (Barley \& Brigham, 2008). "Potential contributing factors include social and collegial isolation, low salaries, 
multiple grade or subject teaching assignments, and lack of familiarity with rural schools and communities. Together, these challenges can discourage teachers from accepting rural positions or cause them to leave rural settings after teaching there for only a short time" (Barley \& Brigham, 2008). Such problems are characteristic not only of the Central Region states of the United States, but also of most rural schools in different countries (Zinger, Haymore Sandholtz \& Ringstaff, 2020). In addition, in rural areas, due to numerous difficulties, there is a greater need for "special psychological training of teachers to prevent and overcome professional burnout" (Kyrian, Nikolaesku, Stepanova \& Nenko, 2020).

It is no coincidence that many scientific articles address the professional development needs of rural school teachers (Glover and others, 2016). Modern scholars (Barley \& Brigham, 2008; Budnyk, Mazur, Kondur et al., 2020) emphasize the lack of research on teacher training in remote rural educational establishments, taking into account the specifics of the organization process in the region. American scientists conducted a cartographic survey of rural education research in the United States, which should provide a powerful impetus for similar research in different countries, "can provide a useful framework for relevant research of urban spaces, as well as rural and urban spaces in various nations" (Thier et al., 2021).

An equally important problem in the organization of education in rural areas is the support of researchers in the field of pedagogical education and rural school heads. After all, we need systematic support for the leadership potential of the rural community (Wargo et al., 2021).

Thus, the relevance of the study is due to the societal challenges faced today by rural remote educational institutions in mountainous regions:

- $\quad$ adaptation of rural schools that are in difficult socio-economic and socio-cultural conditions to provide quality education;

- intensification of social work in schools of remote rural (mountainous) areas;

\section{- $\quad$ improving the material and} technical base of rural schools; availability of digital technologies, in particular in the conditions of distance and blended learning due to the spread of COVID-19;

- providing educational institutions with highly qualified pedagogical staff, the need for professional growth of rural teachers;

\section{support for researchers and}

young leaders in the rural community; 
- $\quad$ the need to develop digital competencies of teachers and students, their information literacy, etc.

So, the purpose of the article is to present the realities and features of work in a typical rural school in a mountainous region, in particular the challenges of distance learning in a coronavirus pandemic; to determine the prospects for the development of remote educational establishments in the Ukrainian Carpathians.

\section{Characteristics of Rural (Mountainous) School}

A rural or mountainous school is usually called an educational establishment, which on a territorial basis is remote from densely populated areas and is located on the outskirts of the country. This concept is sometimes identified with "concept farm school or small school" (Pierre du Plessis, 2014).

The following features are examples of the rural profile (UNESCO, 2005):

-Distance to towns;

-Topography (conditions of roads, bridges to school, etc);

-Access to information technology;

-Transport infrastructure (roads, buses, taxis);

-Access to services and facilities (electricity, water, sanitation);
-The health, educational and economic status of the community;

-Access to lifelong learning services;

-Social conditions in the community;

-Activities of political and civil society organization.

In some post-Soviet countries (for example, Ukraine, Georgia, Belarus) there is the concept of "rural small circle", which characterizes a primary school in which there are fewer teachers than classes, and each teacher conducts lessons simultaneously with two or more classes. Actually, the basis of such a definition is staffing of the student body of the school. This type of school is located mostly in rural areas. In a small school, the total number of students, class size, and number of students per teacher is lower than the normal set by the authorities in the country.

There is research that small rural schools can sometimes be much more effective than large ones in terms of the quality of education, individual approach and motivation of schoolchildren, fuller involvement of parents in the educational process, work with socially disadvantaged children and so on (Raywid, 1999). 
Specifics of the Educational Environment in the Mountain Province

The analysis of scientific and educational literature on the subject of this research has shown the complexity and diversity of the formation of orientations on values among students living in the mountainous region (Ralph, 2002; Maynard \& Howley, 1997).

In the school located in the mountains the influence of landscapegeographical and ethno-cultural environment on the establishment and development of personal values of growing personality (moral, civic, aesthetic) can be clearly observed. The spirituality of the young person operates in this context (Budnyk, 2014). Among them we can differentiate such values as: patriotism-the identity of ethnic community; awareness of the importance of the native language (the language of the ancestry) in the life of the nation; responsibility for the future of the country; respect for other ethnic communities; aesthetic, environmental, valeological, ideological values.

The mountain region is characterized by specific features: colorful nature contributes to the accumulation of vast experience of communication with nature, which results in preserving old traditions formed through the centuries: careful management, spirituality and respectful attitude to the world. The traditional crafts, progressive ritual traditions that certainly serve as an effective factor in the harmonious development of the child were sufficiently preserved here (Budnyk \& Mazur, 2017, pp. 54-55).

Residents of the mountain region are usually deeply religious people who also raise their children in accordance with the religious ideology. So the question arises about the use of Christian ethics and religious elements in the pedagogical process of school in order to understand the religious mentality and establish cooperation with parents and students. Obviously valuable in this context is the knowledge about the positive impact of religion on stress management, mental disorders of children, promotion of social activity in the community, etc. Currently, the system of the individual values worldview is shaped by the global transformation of the hierarchy of human values. So the most important question is the one connected with the study, formation and development of the personal values of a young person, taking into consideration the specifics of the particular region, including mountain landscape and the climatic and socio-cultural environment.

In the schools located in the Ukrainian Carpathians we have a lot of 
potential opportunities to familiarize students with valuable natural resources and unique spiritual and cultural traditions. Therefore, these regions are especially characterized by a number of socioeconomic problems (unemployment, poverty, instability, external migration of the adult population, lower birth rates) and environmental problems (floods, deforestation, etc.). To some extent such issues affect the quality of education so acutely raises the problem of revival and creation of authentic spiritual and moral values of the young person, based on the ideals of truth, goodness, beauty, freedom, education for the real citizen and landlord (Budnyk \& Mazur, 2017, p. 55).

\section{Research methods}

Analytical-synthetic method was used to study the psychological and pedagogical literature on the organization of the educational process in rural schools, the specifics of children's education in mountainous areas, as well as substantiation the problem of using modern digital technologies in distance education in rural (small) schools holistic creative synthesis and analysis.

Empirical methods (survey, comparison) were used to study the state of the problem in school practice, teachers' understanding of tasks and challenges for the use of digital resources and tools of distance teaching in rural (mountain) schools.

Methods of mathematical statistics were used for quantitative and qualitative analysis of the obtained empirical data.

\section{Instruments and Procedures}

The article presents the results of an empirical study conducted in rural schools in the mountains of Ukraine. A survey of teachers working on various levels of education (educators of preschool educational establishments, primary and secondary school teachers, the administration of the educational establishment) was conducted. The anonymous survey involved 114 people representing different age groups. The questions of the questionnaire concerned the attitude of teachers to distance learning in the context of the coronavirus pandemic, the realities and difficulties in the use of information and communication technologies (ICT) in the educational process of rural (small) schools.

\section{Results of Research Regional component of school education}

In the context of multiculturalism and globalization, national education is the key to the preservation and development of the ethnic community. Therefore, an 
important task of the modern rural school is to pass on to the younger generation ethno-cultural heritage in the broadest sense of the word, taking into account the landscape-climatic, demographic, ethnographic characteristics of the region while teaching and educating students.

Rural (mountain) schools and districts tend to be smaller in number of students served, respectively, offering a more limited choice of extracurricular activities of arts, socio-cultural, health or STEM education (Goodpaster, Adedokun \& Weaver, 2012). But in addition to the problems, rural conditions also provide a number of unique benefits for students in the regional component of educational content. There are significant opportunities for the creativity of a rural teacher. First of all, it is a unique natural and ethno-cultural environment, and "include the local funds of knowledge present in rural communities broadly, as well as the backgrounds and daily experiences of rural school-aged children" (Avery \& Kassam, 2011).

In the educational process, the best teachers of rural remote schools conduct "open-air lessons", use rich natural learning materials, as well as opportunities for observation and experimentation with natural objects. This is especially true for training in today's coronavirus pandemic.
An example of this historically and culturally developed knowledge is students' experiences fishing, hunting, and interacting with indigenous knowledge. It is within this dynamic system that rural schools and districts are charged with preparing students to meaningfully engage with science in ways that help them make sense of the world (NGSS Lead States, 2013). The Next Generation Science Standards (NGSS), introduced in 2013, call for significant shifts in the way science is taught (Zinger et al., 2020, p. 14).

The colorful nature of the region (mountains, forests, meadows, rivers) contributes to the accumulation of vast experience in nature management, as a result of which the inhabitants of remote rural areas have formed centuries-old management traditions. We believe that the development of ecological and economic competence of students in rural (mountain) schools should be carried out taking into account the economic traditions of local residents. For example, through the narrow valleys of mountain rivers built woodenstone dams to strengthen the banks, especially in places of sharp turns. The current floods in the mountainous regions of the Ukrainian Carpathians testify to the objective need to revive and continue the ancient traditions of intelligent nature management. 
Thus, the pedagogical experience of villagers is widely represented in the traditions of management, respect for the world, customs, rituals, etiquette, beliefs, folk art, games, toys, food, architecture, symbols, crafts and more. Elements of socio-culture are more or less part of the content of education of a modern rural school in the Ukrainian Carpathians. Accordingly, the system of knowledge and skills to be acquired by students should be adapted to specific socio-cultural conditions and traditions. Therefore, in such a school it is important to use the regional component in the content of education for the development of students' relevant competencies in the field of ethnoculture.

\section{Digitization of Education in Rural Schools}

The challenges of distance learning in remote rural schools have highlighted a number of problems in the organization of quality education, primarily related to the logistics of rural schools, including mountain schools in the Ukrainian Carpathians.

Wallin and Reimer (2008) note that rural educational institutions often face difficulties such as: (a) isolation from specialized services; (b) limited accessibility to quality staff, development and university services; (c) lack of teachers; and (d) decreasing enrolment which leads to decreased funding.

Teachers in rural schools experience numerous serious challenges. Most of the children do not attend school regularly as they are forced to work on farms, and they are not encouraged to attend school. Learners who do attend school often find the curriculum not relevant to their lives and find that their learning is not supported at home. The economic constraints of governments to provide free basic education to all its citizens and the low socioeconomic status of parents are serious barriers preventing children from receiving a high standard of education and experiencing quality of life. This is particularly true in Africa and other developing countries around the world, where the majority of people live in poverty and do not have access to quality education. Although governments are increasingly concerned with issues of teacher development, the focus is often more on urban schools, resulting in rural schools being neglected (Du Plessis \& Mestry, 2019).

At the same time, it is necessary to provide quality general secondary education for all students, regardless of the area in which they live, in order to balance their chances of continuing their education in colleges or universities. After all, the legislation on education in most countries of the world is to ensure equal access for all students to high quality education. At the same time, we do not have enough research to analyze academic 
achievements, access to educational services for students in rural and urban schools (Hudacs, 2020).

Theoretical analysis of the scientific literature shows that the digitalization of education helps to improve its quality, because today there is a tendency to increase the number of free digital tools, educational platforms and electronic resources for online and offline learning. This greatly facilitates the work of the teacher in terms of distance or blended learning. At the same time, the rural school has some problematic issues regarding the use of information and communication technologies in working with students (Budnyk \& Kotyk, 2020).

ICT significantly increases students' motivation to learn, their interest in online communication, overcomes sociopsychological barriers to learning, children from remote places have access to a variety of didactic materials in an acceptable format, as well as have the opportunity to demonstrate their learning achievements and develop soft skills. Personal computers, SMART-boards, and the Internet today serve as necessary tools in professional activities to create an appropriate educational environment for the educational establishment, and therefore - in the remote work of teachers using digital innovations with students.
Actually for this purpose in each school it is necessary to create the corresponding educational environment for e-learning.

The digital environment is a place where conditions are created for the use of technologies and digital devices that are often transmitted over the Internet and other digital means (for example, through a mobile telephone network). The term "digital environment" is mostly used in a general sense (as a specific background for digital activities) without the name of a specific technology or tool (Vuorikari et al., 2016). In the pedagogical context, such an environment also involves the use of special educational programs, educational platforms, virtual laboratories, etc. to organize the process of acquiring new knowledge in the educational establishment, increasing foreign language competence and expanding the experience of educational communication, including online (Vovk, 2017).

The digital educational environment in rural schools also helps to stimulate cognitive interests in learning, creating an accessible educational environment for children with special educational needs. After all, in the inclusive process, ICTs expand the following opportunities: provide access to educational resources as a compensatory tool at a convenient time and place for individual learning at home, 
including with parents (guardians); help to perform tasks taking into account the peculiarities of their development, at their own pace; if necessary, students have the opportunity to repeat the theoretical or practical material; conditions for selfdevelopment, search of educational information from various sources, exchange of messages and multimedia data, etc.

We see an important advantage of using ICT in an educational establishment in the opportunities to develop skills of independent work of rural school students (Budnyk \& Kotyk, 2020). After all, the correct use of computers in primary school lessons, even if it is online learning, significantly increases the intensity of learning. The use of a number of digital resources: educational games, videos, interactive platforms, etc. also allows for correctional and developmental work with students with special educational needs in an inclusive classroom, to differentiate and individualize the educational process. This activates the perception of children, their attention, improves memory, increases motivation for learning.

At the same time, remote regions have some problems with the creation and operation of an effective digital learning environment for students. During COVID19 pandemic, when all schools studied remotely, these problems were exacerbated by the lack of high-speed Internet, highquality computers in remote settlements (depressed areas), as well as the willingness of teachers to use digital resources and tools online and others (Dube, 2020).

To identify the attitude of teacherspractitioners of different levels of rural education (preschool, primary and secondary school) to distance learning, we conducted an empirical study. Among the survey participants, $89.47 \%$ were women and $10.53 \%$ were men. This gender ratio is explained by the dominance of women in the teaching profession, at least it is typical for European countries, including Ukraine, Poland, France and others. The survey was conducted in educational establishments of Ukraine (mountainous region of the Ukrainian Carpathians).

To the question "How do you feel about distance teaching in modern conditions?" The majority of rural school teachers in the mountainous region $49.12 \%$ answered positively, $18.42 \%$ - partially supported, $8.77 \%$ - didn't not see any problem for the organization of the educational process (Fig. 1), because rural schools are usually small in number of children.

Conversations with teachers confirm that their opinions are explained by the 
following reasons: 1) some students from low-income families do not have modern computers (laptops) to study; 2) some students living in high-altitude remote areas often cannot connect to the Internet; 3) rural infrastructure is not always favorable for online learning; 4) in rural schools there are not enough digital technologies for high-quality innovative education of students; 5) a significant number of rural teachers do not have the skills to use modern digital technologies, including gadgets; 6) there are not enough educational platforms for distance learning of students in their native language, etc.

Apparently, due to these difficulties, almost a quarter of respondents (23.68\%) are categorically against distance learning of students in a rural (incomplete) school.

Figure 1 - The attitude of rural school teachers to distance learning students.

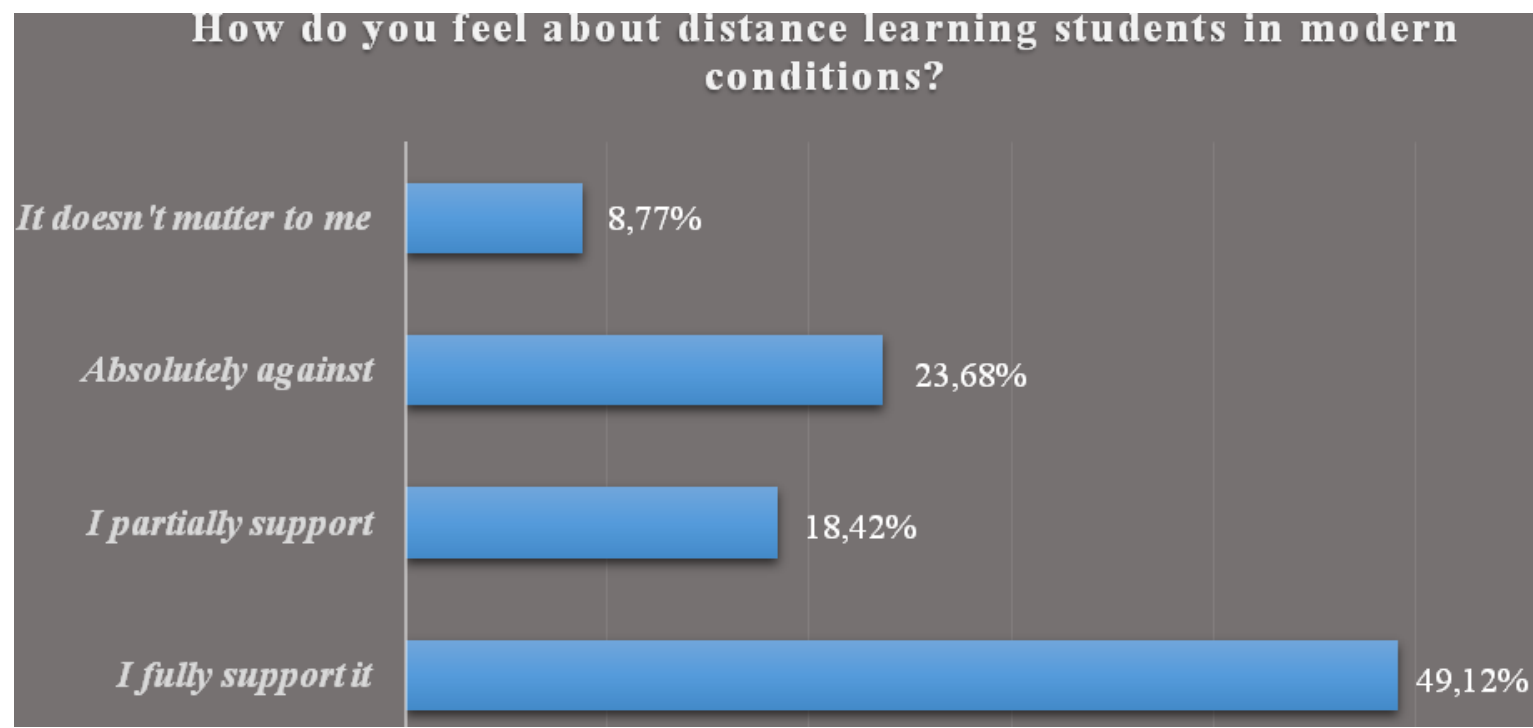

Source: The survey was conducted by the authors of the article.

In order to investigate which digital resources and teaching tools are known to rural school teachers, we conducted the following survey, the results of which are presented in Figure 2. 
Figure 2 - Digital tools for organizing distance learning of students (at the choice of rural school teachers).

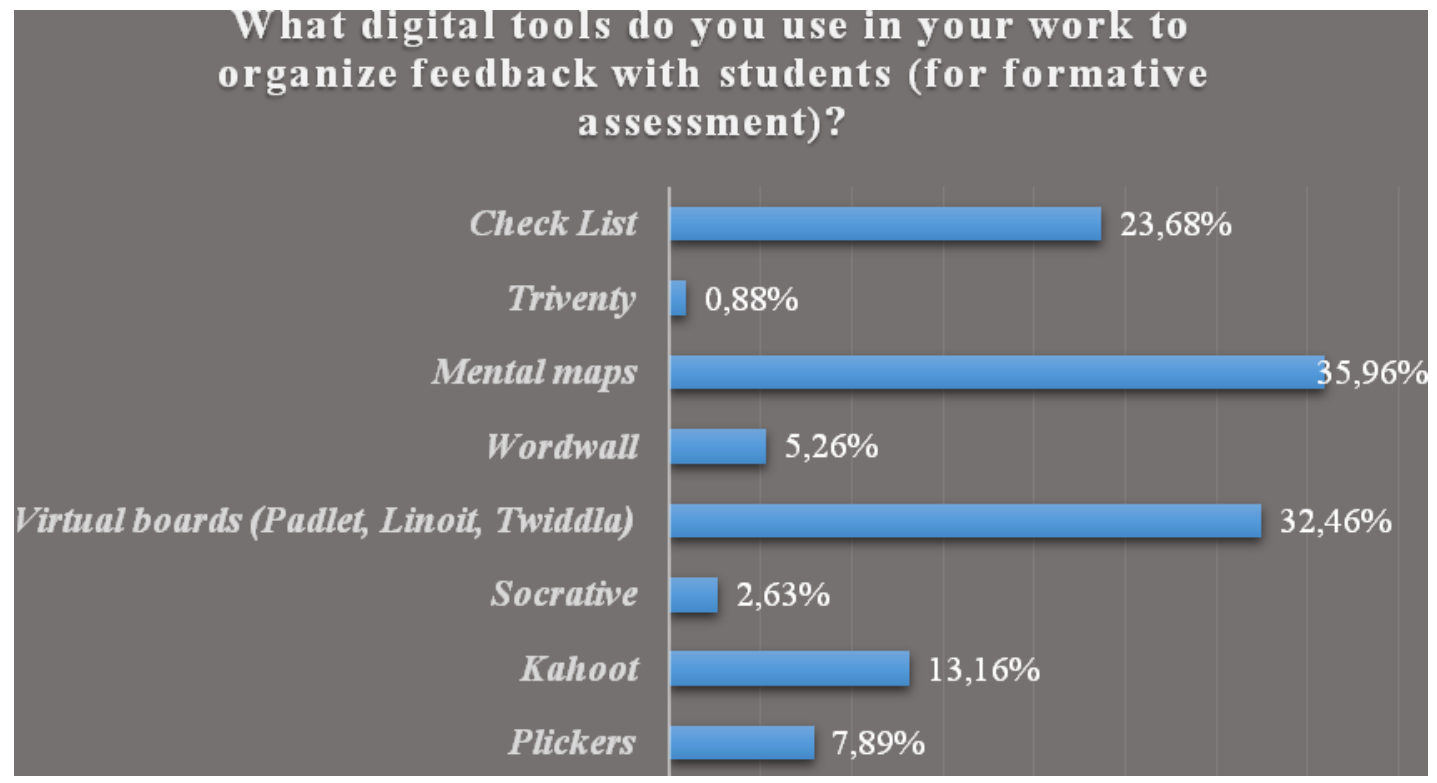

Source: The survey was conducted by the authors of the article.

As we can see, rural school teachers have information about digital technologies for formative assessment of student learning outcomes and providing feedback in the educational process. At the same time, due to the above difficulties, these resources are mostly not used in distance learning of schoolchildren. The most popular among children and teachers are services for creating mental maps (as stated by $35.96 \%$ of respondents) and virtual boards (32.46\%). A significant number of teachers (22.68\%) use a checklist in their work with students, primarily to organize independent work in quarantine. At the same time, checklists are used for formative assessment of students' learning outcomes. Among such digital instruments, respondents also pointed to Kahoot (13.16\%) and Plickers (7.89\%), with only $2.63 \%$ using Socrative for such purposes.

Therefore, based on this survey, it can be argued that school teachers located in remote rural areas have, among other things, difficulties in applying innovative digital techniques to work with students in a remote or mixed format.

Today, when there is still a pandemic hazard (COVID-19) and educational establishments around the world operate in closed or mixed formats, e-learning involves the remote acquisition of new skills and management using appropriate learning platforms and digital tools, is extremely valuable. Digital competence of 
teachers and students is also a necessary condition for awareness of legal and ethical principles regarding the use of information technology, digital services, critical attitude to the received information and general adequate employment of modern media for personal or educational purposes.

In addition, online learning has certain risks for students, as they work on the Internet, where they are always tempted to visit social networks or dangerous sites. In distance learning, particularly in rural schools, this process is often uncontrolled. Therefore, it is extremely important for teachers to form media literacy and a culture of student behavior in a networked environment. Media literacy is interpreted as a "skill set that promotes critical engagement with messages produced by the media" (Bulger \& Davison, 2018, p. 3). "Reflective and metacognitive thinking is a key dimension of media literacy and that this practice continues to be essential today. But reflective thinking is not purely personal. Reflective thinking is fundamentally social” (Hobbs \& McGee, 2014). Considerable attention is also paid to the issues of leisure and leisure of children in these remote regions (Budnyk et al., 2020).

\section{Conclusions}

1. In order to improve the quality of education in rural schools, close cooperation with the community is needed: "rural parents, students, community groups can add valuable information to discussions about educational adequacy and, therefore, they should be fully involved in the process of defining and costing out an adequate education" (Malhoit, 2005, p. 4). It is the community that is decisive in making key decisions and directing all its efforts on educational policy in rural schools to improve the quality of student learning.

2. Difficulties in the use of digital resources and tools in the educational process of rural schools are due to: lack of high-speed Internet, insufficient technical equipment of educational establishments; often low and medium level of preparation of teachers for the use of gadgets in the educational process; insufficient motivation of teachers to use digital innovations in education; lack of guidelines for the use of digital technologies in the education of rural school students, etc (Budnyk \& Kotyk, 2020). Therefore, in order to solve these and other problems, systematic support is needed for rural (small) schools located in depressed remote mountainous regions. After all, under COVID-19, a significant 
number of rural students have lost access to quality education due to a lack of resources to connect to the Internet, a learning management system and low-tech software in developing countries. Therefore, we must ensure social justice and the rights of students studying in rural areas, in particular in high-altitude remote areas.

3. In today's world, it is impossible to avoid the influence of the media, network environment, so it is necessary to establish cooperation between teachers and parents in the formation of media literacy of students in rural (mountain) schools. This includes greater control over the use of gadgets and the Internet by students for educational purposes. After all, under the influence of the media the so-called "passive" intellectual, physical and emotional development of the individual is observed (information presented in a ready-made form is often not subject to critical analysis).

4. For the practical solution of the outlined problem we consider effective active cooperation of pupils, teachers, parents, community, authority in project activity for support of rural schools, their digitalization, improvement of material and technical base, maintenance of universal educational design, etc.

\section{References}

Avery, L. M., \& Kassam, K. S. (2011). Phronesis: Children's local rural knowledge of science and engineering. Journal of Research in Rural Education, 26(2), 1-18. https://jrre.psu.edu/sites/default/files/201908/26-2.pdf

Barley, Z. A., \& Brigham, N. (2008). Preparing teachers to teach in rural schools (Issues \& Answers Report, REL 2008-No. 045). Washington, DC: U.S. Department of Education, Institute of Education Sciences, National Center for Education Evaluation and Regional Assistance, Regional Educational Laboratory Central. Retrieved from http://ies.ed.gov/ncee/edlabs

Bulger, M., \& Davison, P. (2018). The Promises, Challenges and Futures of Media Literacy. Journal of Media Literacy Education, 10(1), 1-21.

Budnyk, O. (2014). Teachers' Training for Social and Educational Activity in Conditions of Mountain Area Primary School. Journal of Vasyl Stefanyk Precarpathian National University, 1(2-3), 22-27. https://doi.org/10.15330/jpnu.1.23.22-27

Budnyk O., \& Kotyk M. (2020). Use of Information and Communication Technologies in the Inclusive Process of Educational Institutions. Journal of Vasyl Stefanyk Precarpathian National University, $\quad 7(1), \quad 15-23$. https://doi.org/10.15330/jpnu.7.1.15-23

Budnyk, O., \& Mazur, P. (2017). The Hierarchy of Values Among Young People from Schools in the Mountainous Regions (Comparative study on the example of Poland and Ukraine. The New Educational Review, 47(1), 53-65. https://doi.org/10.15804/tner.2017.47.1.04. https://tner.polsl.pl/e47/a4.pdf 
Budnyk O., Mazur P., Kondur O., Smoliuk S., \& Palahniuk M. (2020). The problem of spare time of teenagers in mountain regions of Poland and Ukraine. Revista Inclusiones, 7(Número Especial), 493-507. http://revistainclusiones.org/pdf13/40\%20 VOL\%207\%20NUM\%20ESPECIALJULI OSEPTIEMBREEE2020ZZ.pdf

Budnyk, O., Nikolaesku, I., Atroshchenko, T., Shevchenko, A., Chinchoy, A., Yatsyna, S., \& Zobenko, N. (2021). Professional training of teachers for social and pedagogical activity: progressive world practices. Revista Inclusiones, 8(Especial), 20-31.

Dube, B. (2020). Rural Online Learning in the Context of COVID-19 in South Africa: Evoking an Inclusive Education Approach. Multidisciplinary Journal of Educational Research, 10(2), 135-157. https://doi.org/10.4471/remie.2020.5607

Hobbs, R., \& McGee, S. (2014). Teaching about propaganda: An examination of the historical roots of media literacy". Journal of Media Literacy, 6(2), 56-67.

Hudacs, A. (2020). An examination of college persistence factors for students from different rural communities: A multilevel analysis. Journal of Research in Rural Education, 36(2). https://doi.org/10.26209/jrre3602

Glover, T. A., Nugent, G. C., Chumney, F. L., Ihlo, T., Shapiro, E. S., Guard, K., \& Bovaird, J. (2016). Investigating rural teachers' professional development of instructional knowledge, and classroom practice. Journal of Research in Rural Education, 31(4), 1-16. https://files.eric.ed.gov/fulltext/EJ1101917. pdf

Goodpaster, K. P., Adedokun, O. A., \& Weaver, G. C. (2012). Teachers' perceptions of rural STEM teaching:
Implications for rural teacher retention. Rural Educator, 33, 9-22.

Kyrian, T., Nikolaesku, I., Stepanova, N., \& Nenko, Y. (2020). Relationship between Professional Burnout of Teachers of Higher Education Institutions of Ukraine and Their Organizational, Professional and Socio-demographic Characteristics. Revista Romaneasca Pentru Educatie Multidimensionala, 12(4), 268-288. https://doi.org/10.18662/rrem/12.4/345

Maynard, S., \& Howley, A. (1997). Parent and community involvement in rural schools. ERIC Digest. Charleston, WV: ERIC Clearinghouse on Rural Education and Small Schools. (ERIC Document Reproduction Service No. 408143). http://www.eric.ed.gov/ERICDocs/data/eri cdocs2sql/content_storage_01/0000019b/8 $\underline{0 / 16 / 9 d / d 5 . p d f}$

Malhoit, G. C. (2005). Providing Rural Students with a High Quality Education: The Rural Perspective on the Concept of Educational Adequacy. A Publication of the Rural School and Community Trust, The Rural School and Community Trust. Printed in the United States of America. https://www.ruraledu.org/user_uploads/file /Providing_Rural_Students.pdf

Du Plessis, P. (2014). Problems and Complexities in Rural Schools: Challenges of Education and Social Development. Mediterranean Journal of Social Sciences, 5(20), 1109-1117. https://doi.org/10.5901/mjss.2014.v5n20p1 $\underline{109}$.

https://pdfs.semanticscholar.org/5d72/519e 43394bf2b9f39a042569a9d02c8621bb.pdf

Du Plessis, P., \& Mestry, R. (2019). Teachers for rural schools - a challenge for South Africa. South African Journal of Education, 39(1), 1-9. http://www.scielo.org.za/pdf/saje/v39s1/02 . .pdf 
Ralph, E. G. (2002). Teaching in rural schools: A synthesis of interns and cooperating teachers' views. The Rural Educator, 24(2), 13-22.

Raywid, M. A. (1999). Current literature on small schools. ERIC/CRESS, EDO-RC98-8. Appalachian Educational Laboratory. https://files.eric.ed.gov/fulltext/ED425049. pdf

Thier, M., Longhurst, J. M., Grant, P. D., \& Hocking, J. E. (2021). Research deserts: A systematic mapping review of U.S. rural education definitions and geographies. Journal of Research in Rural Education, 37(2),

$1-24$. https://doi.org/10.26209/jrre3702

Zinger, D., Haymore Sandholtz, J., \& Ringstaff, C. (2020). Teaching Science in Rural Elementary Schools: Affordances and Constraints in the age of NGSS. The Rural Educator, 41(2), 14-30. https://doi.org/10.35608/ruraled.v41i2.558

UNESCO. (2005). Education for all by 2015. Will we make it? EFA Global Monitoring Report 2008, Paris: UNESCO. Vovk, O. I. (2017). Foreign Language Acquisition: a Communicative and Cognitive Paradigm. Science and Education, $\quad 6, \quad 81-85$. https://doi.org/10.24195/2414-4665-20176-13

Vovk, O. I. (2017). Foreign Language Acquisition: a Communicative and Cognitive Paradigm. Science and education, 6, 81-85. https://doi.org/10.24195/2414-4665-2017$\underline{6-13}$

Vuorikari, R., Punie, Y., Carretero Gomez, S., \& Van Den Brande, G. (2016). DigComp 2.0: The Digital Competence Framework for Citizens. Publications Office of the European Union. https://doi.org/10.2760/38842. https://ec.europa.eu/jrc/en/digcomp/digitalcompetence-framework

Wallin, D. C., \& Reimer, L. (2008) Educational priorities and capacity: a rural perspective. Canadian Journal of Education, 31(3), 591-613.

Wargo, E., Budge, K., Carr-Chellman D., \& Canfield-Davis, K. (2021). Leadership for rural school district improvement: The case of one statewide research practice partnership. Journal of Research in Rural Education, $\quad 37(1)$, 1-18. https://doi.org/10.26209/jrre3701.

\section{Article Information \\ Received on July 13th, 2021 \\ Accepted on July 20th, 2021 \\ Published on August, 07th, 2021}

\begin{abstract}
Author Contributions: Olena Budnyk was responsible for the theoretical analysis of the problem, critical revision of the content, its editing and review, and approval of the final version published. Inna Nikolaesku and Nataliia Stepanova were responsible for the survey of teachers working in various levels of education (in rural schools) and data analysis and interpretation. Tetiana Atroshchenko was responsible for statistical analysis of the data, as well as a scientific description of the problem regarding the specifics of the teacher's work in the mountainous region. Olena Vovk and Anna Palienko were responsible for the study design, writing the content of the manuscript in English, and approval of the final version published.
\end{abstract}

Conflict of Interest: None reported.

Article Peer Review
Double review.
Funding
No funding.
How to cite this article
APA
Budnyk, O., Nikolaesku, I., Stepanova, N., Vovk, O.,
Palienko, A., \& Atroshchenko, T. (2021). Organization of
the educational process in the Rural School of the
mountain region: a case study. Rev. Bras. Educ. Camp., 6 ,
e12647. http://dx.doi.org/10.20873/uft.rbec.e12647
ABNT
BUDNYK, O.; NIKOLAESKU, I.; STEPANOVA, N.; VOVK,
O.; PALIENKO, A.; ATROSHCHENKO, T. Organization of


Budnyk, O., Nikolaesku, I., Stepanova, N., Vovk, O., Palienko, A., \& Atroshchenko, T. (2021). Organization of the educational process in the Rural School of the mountain region: a case study...

the educational process in the Rural School of the

mountain region: a case study. Rev. Bras. Educ. Camp.,

Tocantinópolis, V. 6, e12647, 2021.

http://dx.doi.org/10.20873/uft.rbec.e12647 